\title{
PENGARUH PENGGUNAAN MEDIA PEMBELAJARAN BERBASIS ICT TERHADAP HASIL BELAJAR PKN KELAS V SD MUHAMMADIYAH 1 KREMBUNG PADA MASA PANDEMI
}

\author{
Okta Fiani Wulan Saputri ${ }^{1}$, Feri Tirtoni ${ }^{2}$ \\ 1,2Program Studi Pendidikan Guru Sekolah Dasar \\ Universitas Muhammadiyah Sidoarjo, Indonesia \\ 1178620600021@umsida.ac.id, 2feri.tirtoni@umsida.ac.id
}

\begin{abstract}
The application of the use of ICT learning media aims to lead students to actively participate in online learning so that it is hoped that this activity can give the impression of meaningful learning and can improve student Civics learning outcomes. The method used in this study is an experiment with a PreExperimental One Group Pretest-Posttest Design. This research was conducted online with a population of 25 students of fifth grade at SD Muhammadiyah 1 Krembung. The sampling technique used was saturated sampling. The research instrument used a test in the form of multiple choice questions with a total of 20 questions. The data collection technique was carried out twice, namely before the treatment (Pretest) and after the treatment (Posttest). The research data were analyzed using descriptive statistics with the $N$-Gain test technique. The results showed that there was an increase in the average value of student learning outcomes by 29.2, namely from the average pretest score of 55 and the posttest average value of 84.2. From the average of the two tests, calculations were made using the $\mathrm{N}$-Gain test which obtained a score of 0.64. Based on the categorization of the $\mathrm{N}$-Gain test, a score of 0.64 is a medium categorization effect. From the results of these studies, it can be concluded that the application of the use of ICT learning media has an effect on students' cognitive learning outcomes in Civics subjects for class V SD Muhammadiyah 1 Krembung.
\end{abstract}

Keywords : ICT learning media, Civics learning outcomes

\section{ABSTRAK}

Penerapan penggunaan media pembelajaran ICT bertujuan untuk menggiring siswa agar berpartisipasi secara aktif dalam pembelajaran secara online sehingga diharapkan dari keaktifan tersebut dapat memberikan kesan belajar yang bermakna dan dapat meningkatkan hasil belajar PKn siswa. Metode yang digunakan pada penelitian ini adalah eksperimen dengan desain PreEksperimental One Group Pretest-Posttest Design. Penelitian ini dilakukan secara online dengan populasi seluruh siswa kelas V SD Muhammadiyah 1 Krembung yang berjumlah 25 orang. Teknik pengambilan sampel menggunakan sampling jenuh. Instrumen penelitian ini menggunakan tes berupa soal pilihan ganda dengan jumlah 20 soal. Teknik pengumpulan data dilakukan sebanyak dua kali yaitu sebelum adanya perlakuan (Pretest) dan sesudah adanya perlakuan (Posttest). Data penelitian dianalisis menggunakan statistik deskriptif dengan teknik uji N- Gain. Hasil penelitian menunjukkan bahwa adanya peningkatan nilai 
rata-rata hasil belajar siswa sebesar 29,2 yaitu dari nilai rata-rata pretest sebesar 55 dan nilai rata-rata posttest sebesar 84,2. Dari rata-rata kedua tes tersebut dilakukan perhitungan menggunakan uji N-Gain yang diperoleh skor sebesar 0,64. Berdasarkan kategorisasi uji N-Gain, skor 0,64 merupakan pengaruh kategorisasi sedang. Dari hasil penelitian tersebut dapat disimpulkan bahwa penerapan Penggunaan media pembelajaran ICT berpengaruh terhadap hasil belajar kognitif siswa pada mata pelajaran PKn kelas V SD Muhammadiyah 1 Krembung.

Kata Kunci : Media Pembelajaran ICT, Hasil Belajar PKn

\section{A. Pendahuluan}

Pada hakikatnya proses belajar mengajar merupakan dua konsep yang tidak dapat terpisah. Konsep tersebut tergabung dalam satu kegiatan interaksi antara guru dengan siswa, siswa dengan siswa pada saat pembelajaran berlangsung. Interaksi antara guru dengan siswa pada saat pembelajaran berlangsung. Interaksi antara guru dengan siswa sebagai makna utama dalam proses pembelajaran yang memegang peranan penting untuk mencapai tujuan pengajaran yang efektif. Seorang guru dalam menyampaikan pesan atau materi kepada siswa perlu adanya penggunaan model dan media sebagai perantara komunikasi agar berjalan secara optimal.

Di masa pandemi COVID-19 saat ini yang mengharuskan pembelajaran online atau Pembelajaran Jarak Jauh (PJJ), peran model dan media sangat penting yaitu sebagai alat bantu untuk memudahkan siswa dalam menerima materi yang disampaikan oleh guru. Media dan model pembelajaran merupakan salah satu saluran yang membantu guru dalam menambah wawasan siswa dalam menerima pembelajaran (Putra, N. Wijayati : 2017)

Siswa akan mendapatkan pengetahuan dan wawasan baru yang semakin

meningkatkan kecerdasannya sehingga siswa mampu menghadapi tantangan yang akan datang. Maka diharapkan hasil belajar siswa dapat meningkat dengan adanya model dan media sebagai alat bantu dalam penyampaian materi di masa pandemi COVID 19 saat ini. Dampak dari pandemi COVID-19 ini sangat berpengaruh bagi pembelajaran diseluruh jenjang pendidikan, salah satunya yaitu jenjang sekolah dasar. Di sekolah dasar banyak sekali mata pelajaran 
yang harus ditempuh oleh siswa, salah satunya adalah mata pelajaran Pendidikan Kewarganegaraan (PKn). Terdapat beberapa hambatan dalam pembelajaran PKn di beberapa Sekolah Dasar (SD) dalam membentuk kepribadian moral siswa dinilai belum optimal. Rendahnya kreatifitas guru dalam pelaksanaan proses pembelajaran menjadi salah satu faktor penyebabnya. Kurangnya keefektifan dalam pengelolaan pembelajaran akan menyebabkan kurang bermaknanya materi yang diajarkan. Berdaasarkan hasil pengamatan melalui siswa kelas $\mathrm{V}$, Selama ini pembelajaran PKn dianggap sebagai pelajaran yang mementingkan hafalan semata, kurang menekankan aspek penalaran sehingga menyebabkan perhatian siswa sangat kurang, baik terhadap guru, mata pelajaran dan materi yang disampaikan.Hal tersebut tentunya sangat berpengaruh terhadap hasil belajar siswa. Berdasarkan hasil wawancara dengan Wali Kelas V hasil belajar peserta didik sebagian belum mencukupi Kriteria Ketuntasan Minimum (KKM), hal ini dapat dilihat dari nilai Penilaian Akhir Semester (PAS) tahun ajaran 2020/2021 dimana jumlah siswa dikelas $\mathrm{V}$ berjumlah 25 orang, yang terdiri dari 13 orang siswa laki-laki dan 12 orang siswa perempuan, dengan rata-rata peserta didik memperoleh nilai 65 , sedangkan KKM yang ditetapkan di SD Muhammadiyah 1 Krembung adalah 75. Nilai ujian tersebut masih tertinggal jauh dari KKM yang sudah di tetapkan oleh sekolah. Berdasarkkan hasil wawancara dengan wali kelas $V$ SD Muhammadiyah 1 Krembung beliau mengatakan bahwa mata pelajaran PKn memang kurang diminati oleh siswa. Beliau mengatakan bahwa ketika materi yang diajarkan lebih mudah, mereka menyepelehkan dan beranggapan sudah mengerti. Sedangkan ketika materi yang diajarkan lebih sulit, mereka mengeluh karena terkesan banyak yang harus dipahami dan dihafalkan. Dari hasil observasi yang telah dilakukan selama proses pembelajaran online berlangsung guru melaksanakan pembelajaran dengan metode ceramah. Selain itu terbatasnya variasi media dalam proses belajar mengajar secara daring. Materi pembelajaran $\mathrm{PKn}$ yang di dominasi teori jika tidak didukung penggunaan 
model pembelajaran yang sesuai dan media pembelajaran yang tepat akan menyulitkan siswa dalam memahaminya, sehingga pembelajaran PKn di SD terkesan menjadi sulit dipahami oleh siswa.

Karena ketika guru meminta siswa untuk bertanya tentang suatu hal yang belum dipahami, mereka hanya diam dan malas untuk bertanya. Sehingga dari hal tersebut mengakibatkan banyak siswa yang belum mendapatkan hasil belajar secara maksimal. Melihat fakta di atas maka yang harus dilakukan oleh guru adalah mencari solusi yang tepat dalam mengatasi permasalahan tersebut, karena jika hal itu dibiarkan maka hasil belajar siswa akan semakin menurun. Salah satu upaya yang dapat dilakukan untuk meningkatkan hasil belajar terutama ranah kognitif pada mata pelajaran PKn adalah menerapkan penggunaan media pembelajaran ICT (Information and Comunication Technology) dengan menggunakan software Articulate Storyline. yang sudah di desain sedemikian rupa sehingga fungsinya tidak lagi sebagai penampil presentasi melainkan sudah beralih menjadi media pembelajaran interaktif. Tujuan peneliti menerapkan penggunaan media pembelajaran ini adalah untuk menggiring siswa agar berpartisipasi secara aktif dalam pembelajaran online sehingga diharapkan dari keaktifan tersebut dapat memberikan kesan belajar yang bermakna dan dapat meningkatkan hasil belajar kognitif siswa. Media ini berfungsi untuk menyampaikan pesan yang lebih realitas secara langsung mengatasi keterbatasan ruang dan waktu serta menyajikan informasi secara menyeluruh (S. Sukardi Rozi : 2019). Media pembelajaran yang berbasis ICT (Information and Comunication Technology) bukan hanya media yang menggunakan alat indera penglihat ataupun pendengaran saja, tetapi perpaduan antara dua indera tersebut dengan menyajikan foto gambar ataupun video (Maria Zulfiati : 2015). SD Muhammadiyah 1 Krembung merupakan salah satu sekolah yang juga melaksanakan pembelajaran daring guna berupaya dalam mencegah pertambahan kasus penyebaran virus covid-19. Dari pemaparan diatas, penerapan penggunaan media pembelajaran ICT diduga akan memberikan pengaruh 
terhadap hasil belajar kognitif siswa. Berdasarkan permasalahan diatas, maka dilakukan penelitianyang bertujuan untuk mengetahui apakah ada Pengaruh dari Penggunaan Media Pembelajaran Berbasis ICT Terhadap Hasil Belajar PKn Siswa Kelas V Sd Muhammadiyah 1 Krembung Pada Masa Pandemi.

\section{B. Metode Penelitian}

Penelitian ini menggunakan desain penelitian Pre- Experimental Design. Sedangkan untuk design yang digunakan adalah desain One-Group Pretest-Postest Design. Pola design penelitian ini ditampilkan pada gambar 1 : (Sugiyono : 2013)

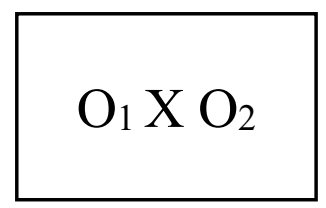

Gambar 1. Desain Penelitian OneGroup Pretest-Postest Design

Keterangan:

$\mathrm{O}_{1} \quad$ : Nilai Pretest (sebelum diberi perlakuan)

$\times \quad$ : Treatment yang diberikan $\mathrm{O}_{2} \quad$ : Nilai Postest (setelah diberi perlakuan)

Media penelitian ini peneliti menggunakan media pembelajaran Articulate Storyline berbasis ICT (Information and Communication
Technology). Articulate Storyline adalah perangkat lunak yang yang dapat digunakan untuk membuat media pembelajaran yang lebih interaktif. dimana hasil publish media pembelajarannya dapat berupa link atau aplikasi yang dapat digunakan melalui HP (Rohmah Bukhori 2017). Subjek penelitian ini adalah siswa kelas 5 SD Muhammadiyah 1 Krembung yang berjumlah 25 siswa. Kemudian data penelitian ini didapatkan dari dokumentasi berupa foto kegiatan saat pembelajaran $\mathrm{PKn}$ kelas V SD Muhammadiyah 1 Krembung dan lembar penilaian kognitif diperoleh dari hasil Observasi.

Sebelum instrumen penelitian digunakan, dilakukan uji validtas dan uji reliabilitas. Pada penelitian ini, peneliti menggunakan uji validitas untuk mengukur ketepatan soal yang akan diujikan kepada responden. Dalam penelitian ini, peneliti menggunakan uji validitas konstruk. Untuk menguji validitas konstruk dapat menggunakan software SPSS 23 untuk mengetahui apakah instrumen tersebut valid atau tidak. Hasil dari perhitungan validitas konstruk ditunjukkan pada tabel 2. 
Tabel 2. Rekapitulasi Hasil Validasi Ahli

\begin{tabular}{|c|c|c|c|}
\hline No & $\begin{array}{c}\text { Jenis } \\
\text { Perangkat }\end{array}$ & Presentase & Keterangan \\
\hline 1 & Silabus & $91 \%$ & $\begin{array}{c}\text { Sangat valid } \\
\text { dan dapat } \\
\text { digunakan } \\
\text { tanpa revisi }\end{array}$ \\
\hline 2 & RPP & $90 \%$ & $\begin{array}{l}\text { Sangat valid } \\
\text { dan dapat } \\
\text { digunakan } \\
\text { tanpa revisi }\end{array}$ \\
\hline 3 & $\begin{array}{c}\text { Bahan } \\
\text { Ajar }\end{array}$ & $90 \%$ & $\begin{array}{c}\text { Sangat valid } \\
\text { dan dapat } \\
\text { digunakan } \\
\text { tanpa revisi }\end{array}$ \\
\hline 4 & LKPD & $87 \%$ & $\begin{array}{l}\text { Valid dan } \\
\text { dapat } \\
\text { digunakan } \\
\text { dalam } \\
\text { penelitian }\end{array}$ \\
\hline 5 & $\begin{array}{c}\text { Instrumen } \\
\text { Soal }\end{array}$ & $86 \%$ & $\begin{array}{l}\text { Valid dan } \\
\text { dapat } \\
\text { digunakan } \\
\text { dalam } \\
\text { penelitian }\end{array}$ \\
\hline 6 & $\begin{array}{c}\text { Instrumen } \\
\text { Media }\end{array}$ & $90 \%$ & $\begin{array}{l}\text { Sangat valid } \\
\text { dan dapat } \\
\text { digunakan } \\
\text { tanpa revisi }\end{array}$ \\
\hline
\end{tabular}

Dari data instrumen pada Tabel

2, menunjukkan bahwa instrumen perangkat pembelajaran yang akan digunakan peneliti dinyatakan valid dan dapat digunakan dalam penelitian. Penelitian ini dilaksanakan pada siswa kelas V SD Muhammadiyah 1 Krembung yang berjumlah 25 siswa. Setelah melaksanakan uji validtas,peneliti melaksanakan uji reliabilitas. Uji reliabilitas dilakukan untuk menentukan apakah instrumen yang akan digunakan dalam sebuah penelitian sudah reliabel (tetap) atau belum. Untuk menghitung nilai reliabilitas instrumen tes digunakan rumus Split-Half yang berbantuan SPSS 23.0. Indikator untuk mengetahui tingkat reliabilitas ditunjukkan pada tabel 3 (Dhamayanti : 2018).

Tabel 3. Kategori Koefisien Reliabilitas Split-Half

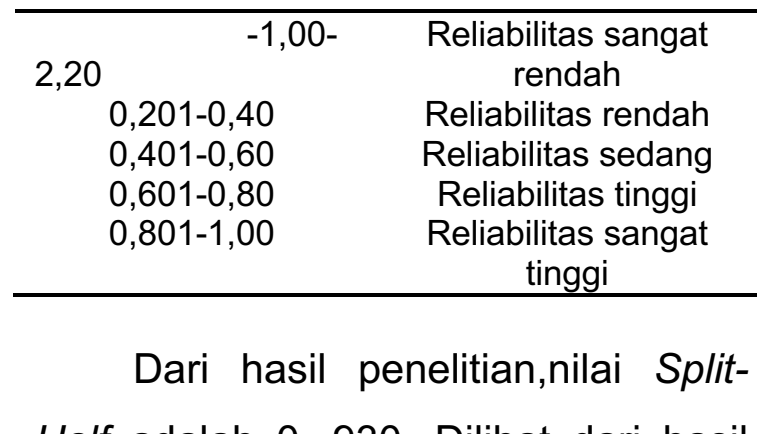
Half adalah 0, 930. Dilihat dari hasil dengan nilai koefisien reliabiltisnya sebesar 0,930 sehingga semua soal dinyatakan reliabiltasnya sangat tinggi.

\section{Teknik Pengumpulan Data}

Teknik pengumpulan data yang digunakan dalam penelitian ini adalah tes.ada dua aspek penting dalam penggunaan tes, soal tes harus memenuhi syarat validitas dan reliabilitas. Sehingga soal tes yang diujikan harus mencakup kedua syarat 
tersebut sebelum diujikan kepada responden. Penelitian ini menggunakan tes unjuk kerja siswa. Tes ini diberikan kepada siswa sebelum dan setelah siswa menerapkan pembelajaran dengan menggunakan media pembelajaran Articulate Storyline. Tujuannya adalah agar mengetahui seberapa besar pengaruh media pembelajaran Articulate Storyline terhadap hasil belajar Siswa kelas $\mathrm{V}$ SD Muhammadiyah 1 Krembung ketika tes sudah di berikan. Bentuk tes yang dimaksud adalah tes unjuk kerja.

\section{Teknik Analisis Data}

Setelah melakukan pengumpulan data, selanjutnya data tersebut dianalisis. Dalam hal ini teknik analisis data bertujuan untuk mengetahui adanya pengaruh antara media pembelajaran Articulate Storyline terhadap hasil belajar siswa pada mata pelajaran PKn kelas $V$ SD Muhammadiyah 1 Krembung. Data yang diperoleh selama penelitian yang berupa pretest dan \& Posttest selanjutnya diolah dan dianalisis menggunakan statistik deskriptif. Statistik deskriptif ini digunakan untuk mengolah data populasi, sehingga tidak memerlukan generalisasi (Sugiyono : 2012) . yang mana berfungsi untuk mengetahui adakah pengaruh media pembelajaran Articulate Storyline terhadap hasil belajar Siswa kelas V SD Muhammadiyah 1 Krembung saat mata pelajaran PKn berlangsung.

Setelah melakukan uji reliabilitas, peneliti melakukan uji uji N-Gain. Pola design penelitian ini ditampilkan pada gambar 4 (Rafmana : 2018) .

Tabel 4. Rumus N-Gain
$N-$ Gain $=\frac{\text { skor posttest }- \text { skor pretest }}{\text { skor ideal }- \text { skor pretest }}$

Keterangan:

1. Tinggi untuk N-Gain $>0,7$

2. Sedang untuk N-Gain 0,3-0,7

3. Rendah untuk $N$-Gain $<0,3$

Untuk mengukur seberapa besar Pengaruh Penggunaan Media Pembelajaran ICT terhadap Hasil Belajar PKn Siswa Kelas V SD Muhammadiyah 1 Krembung Pada Masa Pandemi, maka peneliti menggunakan Uji N-Gain. Hasil perhitungan N-Gain dapat dilihat pada tabel 5.

Tabel 5. Uji N-Gain

Rata-rata N-Gain 


$$
55
$$

84,2

0,64

Hasil analisis menunjukkan adanya perbedaan hasil belajar kognitif siswa antara sebelum diberikan perlakuan dengan sesudah diberikan perlakuan. Hal ini dibuktikan berdasarkan hasil penelitian dan perhitungan yang telah dilakukan, dapat diketahui rata- rata pretest 55 dan hasil rata-rata posttest sebesar 84,2. Peningkatan hasil rata-rata pretest dan posttest tersebut dianalisis menggunakan uji N-Gain yang menghasilkan nilai 0,64 . Selanjutnya dari hasil uji N-Gain tersebut dilihat dari kategorisasi N-Gain menunjukkan bahwa nilai 0,64 berada di kategori sedang. Artinya bahwa Pengaruh Penggunaan Media Pembelajaran ICT terhadap Hasil Belajar PKn Siswa Kelas V SD Muhammadiyah 1 Krembung Pada Masa Pandemi berpengaruh terhadap hasil belajar kognitif siswa dengan kategori pengaruh sedang.

\section{Hasil Penelitian dan Pembahasan} Pengambilan data pada pertemuan pertama dilaksanakan pada hari Senin tanggal 26 Juli 2021 hanya memberikan Pretest kepada siswa sebelum diberlakukannya treatment. Pertemuan selanjutnya dilaksanakan pada hari selasa dan Rabu tanggal 27 dan 28 Juli 2021 dengan menerapkan treatment dengan memberikan treatment media pembelajaran ICT dan posttest. Data yang dihasilkan pada penelitian ini diambil dari jumlah nilai pretest dan posttest dengan cara memberikan soal kepada siswa kelas $\mathrm{V}$ sebanyak 20 soal. Hasil dari penelitian ini diperoleh hasil pretest $=1375$ dengan rata-rata 55 dan hasil posttest $=2105$ dengan rata-rata 84,2. Setelah menyajikan data hasil penelitian, peneliti melanjutkan untuk megetahui bagaimana pengaruh peningkatan hasil belajar kognitif siswa sebelum dan sesudah pembelajaran dengan menggunakan media pembelajaran ICT. Peneliti menggunakan rumus $N$ Gain. Hasil perhitungan menunjukkan nilai $\mathrm{N}$-Gain $=0,64$. dari hasil uji $\mathrm{N}$ Gain tersebut dilihat dari kategorisasi $\mathrm{N}$-Gain menunjukkan bahwa nilai 0,64 berada di kategori sedang. Artinya bahwa media pembelajaran ICT memiliki pengaruh terhadap hasil belajar kognitif siswa dengan kategori pengaruh sedang. Berdasarkan hasil analisis perhitungan uji N-Gain, dapat 
disimpulkan bahwa adanya pengaruh dari penggunaan media pembelajaran Articulate Storyline berbasis ICT terhadap hasil belajar siswa kelas $\mathrm{V}$ SD Muhaammaidyah 1 Krembung.

Dengan media pembelajaran Articulate Storyline terlihat adanya beberapa kelebihan diantaranya meningkatkan kerjasama antar anggota, meningkatkan rasa percaya diri siswa saat menjawab pertanyaan dari hasil diskusi, mengembangkan rasa ingin tahu dan meningkatkan hasil belajar siswa. Respon positif yang ditunjukan oleh siswa terlihat dari kehadirannya selama proses treatmet dilaksanakan. mereka tampak bersemangat dan antusias. Media pembelajaran ICT berbasis Articulate Storyline dirancang untuk mempengaruhi pola interaksi siswa sebagai alternatif dari pembelajaran konvensional. Tujuannya adalah membantu siswa memahami materi yang sulit sehingga dapat mencapai hasil belajar yang maksimal. Dalam penelitian ini, penerapan media pembelajaran ICT berbasis Articulate Storyline sangat membantu siswa dalam meningkatkan hasil belajar kognitifnya. Didukung dengan teori yang mengemukakan bahwa Dalam proses belajar dan mengajar yang dilakukan dengan memanfaatkan dan menggunakan teknologi informasi dan komunikasi ini merupakan salah satu bimbingan dari pengajar untuk senantiasa memfasilitasi pembelajaran yang efektif bagi pembelajar didalam melakukan pembelajaran dimasa pandemi Covid19 (Ratih : 2021). Setelah menggunakan media ICT bahwa terdapat perbedaan yang signifikan hasil belajar sistem komputer antara kelompok siswa yang diajarkan menggunakan strategi berbasis ICT dan kelompok siswa yang diajarkan menggunakan metode konvensional. Hal ini berarti, penerapan strategi pembelajaran[9]. Penggunaan Multimedia dalam pembelajaran sangat efektif dan berdaya guna, terutama jika disajikan dengan tepat dan berpotensi membantu untuk mengakses seara luas pengetahuan dan informasi dalam pembelajaran, mempertinggi pengalaman belajar, secara efektif akan mempertinggi aksebilitas lingkungan pembelajaran kelompok-klompok dari beragam siswa dalam mengeksplor materi pelajaran. 


\section{Kesimpulan}

Berdasarkan dari hasil penelitian dan pembahasan, maka peneliti dapat menyimpulkan bahwa ada pengaruh dari penerapan penggunaan media pembelajaran ICT terhadap hasil belajar kognitif siswa kelas V SD Muhammadiyah 1 Krembung. Hal ini dapat dibuktikan dari hasil perhitungan rata-rata nilai pretest dan posttest mengalami peningkatan sebesar 29,2 dari 55 menjadi 84,2. Berdasarkan perhitungan uji $\mathrm{N}$-gain didapatkan nilai 0,6 dan sesuai kategorisasi uji N-Gain, nilai tersebut berada pada kategori sedang.

\section{DAFTAR PUSTAKA}

R. S. Putra, N. Wijayati, and F. Widhi, "Pengaruh Penggunaan Media Pembelajaran Berbasis Aplikasi Android Terhadap Hasil Belajar Siswa," J. Inov. Pendidik. Kim., vol. 11, no. 2, 2017.

S. Sukardi and F. Rozi, "Pengaruh Model Pembelajaran Online Dilengkapi Dengan Tutorial Terhadap Hasil Belajar," JIPI (Jurnal IIm. Penelit. dan Pembelajaran Inform., vol. 4, no. 2, p. 97, 2019, doi: 10.29100/jipi.v4i2.1066.
H. Maria Zulfiati, "Pengaruh Pembelajaran Ips Berbasis Ict (Information and Communications Technology) Dengan Aplikasi Lectora Inspire Dalam Meningkatkan Hasil Belajar Siswa," Jipsindo, vol. 1, no. 1, pp. 39-58, 2015, doi: 10.21831/jipsindo.v1i1.2878.

Sugiyono, Metode Penelitian Kuantitatif,Kualitatif dan R\&D. Bandung: Alfabeta, 2013.

F. N. Rohmah and I. Bukhori, "Pengembangan Media Pembelajaran Interaktif Mata Pelajaran Korespondensi Berbasis Android Menggunakan Articulate Storyline 3," pp. 169182.

M. Dhamayanti, A. D. Rachmawati, N. Arisanti, and E. P. Setiawati, "Validitas dan Reliabilitas Kuesioner Skrining Kekerasan terhadap Anak ' ICAST-C' versi Bahasa Indonesia," vol. 5.

Sugiyono, Metode Penelitian dan Pendekatan Kuantitatif, Kualitatif dan R\&D. Bandung: Alfabeta, 2012.

H. Rafmana and U. Chotimah, "Pengembangan Multimedia Interaktif Berbasis Articulate 
Storyline Untuk Meningkatkan

Motivasi Belajar Siswa Pada

Mata Pelajaran PKn Kelas XI Di

SMA Srijaya Negara

Palembang," J. Bhinneka

Tunggal lka, vol. 05, no. 1, pp.

52-65, 2018, [Online]. Available:

https://ejournal.unsri.ac.id/indeks

.php/jbti/

article/download/7898/pdf.

D. Ratih and W. Ningtias, "Penggunaan Aplikasi Articulate Storyline Dalam Pembelajaran Mandiri Teks Negosiasi Kelas $\mathrm{X}$ Boga di SMK Negeri 2 Singaraja," J. Pendidik. Bhs. dan Sastra Indones., vol. 11, no. 1, pp. 25-36, 2021. 